\title{
Güzel Sanatlar Eğitimi Bölümü Öğrencilerinin Düşünme Stillerinin Çeşitli Değişkenler Açısından İncelenmesi
}

\section{An Analysis on Thinking Styles of Fine Arts Education Department's Students in Terms of Different Variables}

Duygu Ulusoy Yılmaz

Dr. Öğr. Üyesi, Cumhuriyet Üniversitesi, Eğitim Fakültesi, Güzel Sanatlar Eğitimi Bölümü, Müzik Eğitimi Anabilim Dalı email: dulusoy78@gmail.com (DORCID ID: https://orcid.org/0000-0002-0924-3071

\section{Didem Akar}

Yüksek Lisans, Cumhuriyet Üniversitesi, Eğitim Bilimleri Enstitüsü, Müzik Eğitimi Anabilim Dalı email: yddidemakar@gmail.com DORCID ID: https://orcid.org/0000-0001-8877-5748

\footnotetext{
$\checkmark$ iThenticate" gerektirmemektedir.

Atıf (APA 6)/To cite this article

Ulusoy Yılmaz, D., \& Akar, D. (2020). Güzel sanatlar eğitimi bölümü öğrencilerinin düşünme stillerinin çeşitli değişkenler açısından incelenmesi. Atatürk Üniversitesi Güzel Sanatlar Enstitüsü Dergisi, 26(45), 608-619. doi: https://doi.org/10.35247/ataunigsed.763975
}

Makale Gönderim Tarihi/Received: 04/07/2020

Makale Kabul Tarihi/Accepted: 22/09/2020

Makale Yayın Tarihi/Published: 22/10/2020

Research Article/Araştırma Makalesi

$\ddot{O} z$

$\mathrm{Bu}$ araştırmada Müzik Eğitimi ve Resim-İș Eğitimi Anabilim Dallarında öğrenim görmekte olan öğrencilerin düșünme stillerinin belirlenmesi ve düşünme stillerinin farklı değişkenlere göre anlamlı farklılık gösterip göstermediğinin belirlenmesi amaçlanmıstır. Araștırma tasarımı genel tarama modellerinden biri olan ilişkisel tarama modelindedir. Araştırmanın evrenini 2018-2019 öğretim yılında Canakkale Onsekiz Mart Üniversitesi Güzel Sanatlar Eğitimi Bölümü Müzik Eğitimi Anabilim Dalı ve Resim-İs Eğitimi Anabilim Dalında kayıtlı olan 238 öğrenci; örneklemini ise bu bölümlere devam etmekte olan 146 öğrenci oluşturmaktadır. Araştırma verileri, Sternberg ve Wagner (1992) tarafından geliștirilen, Bulus (2006) tarafindan Türkçe güvenirlik çalışması gerçekleştirilen Düşünme Stilleri Ölçeği ve öğrencilerin demografik özelliklerini belirlemek amacıyla araștırmacı tarafindan hazırlanan kișisel bilgi formu kullanılarak toplanmıștır. Araştırmaya katılan öğrencilerin 2018-2019 güz dönemine ait not ortalama verileri öğrenci işlerinden temin edilmistir. Düsünme Stilleri Ölçeği 5 temel alt boyut ve 13 alt boyut olmak üzere 7'li likert tipi 65 sorudan oluşmaktadır. Elde edilen veriler SPSS 23 (IBM) istatistik paket programı kullanılarak analiz edilmistir. Araştırmada elde edilen bulgulara göre Güzel Sanatlar Eğitimi Bölümü öğrencilerinin sırasıyla en çok yasama, liberal ve yargı düşünme stillerini; en az ise muhafazakâr, global ve monarşik düşünme stillerini tercih ettikleri saptanmıştır. Ayrıca ikinci sınıf öğrencilerinde yargı ve anarșik stilin üçüncü ve dördüncü sinıflara göre daha çok kullanıldığı tespit edilmiştir.

Anahtar kelimeler: Düșünme, Düșünme Stilleri, Güzel Sanatlar Eğitimi, Müzik Eğitimi, Resim-Iş Eğitimi

\begin{abstract}
The aim of this study is to demonstrate thinking styles of the students of Music Education and Art and Crafts Education, and to investigate whether different variables have effects on their thinking styles. The research design is one of the general screening models, the relational screening model. Population of this research includes 238 students of Çanakkale Onsekiz Mart University Faculty of Education Department of Fine Arts, Music Education and Art and Crafts Education in 2018-2019 academic year. The sample size includes 146 students of these 2 divisions. The data was collected by using Sternberg-Wagner Thinking Style Inventory (1992), which was validated in Turkish by Buluş (2006), and a personal information form designed by the researcher to record individuals' demographic features. The students' grade histories for fall semester in 2018-2019 academic year were obtained from student affairs office. SternbergWagner Thinking Style Inventory includes 65 questions with 13 thinking style sub-scales of 5 dimensions. The individuals rated themselves based on a 7 point Likert-type scale. The data was analyzed by SPSS 23 (IBM) statistics program. It was shown that the Fine Arts students mostly chose legislative, liberal and judicial thinking styles in respectively. The thinking styles, that the participants chose least, were conservative global and monarchic. The second grade students chose judicial and anarchic thinking styles more than the third and fourth grade students.
\end{abstract}

Keywords: Thinking, Thinking Styles, Fine Arts Education, Music Education, Art and Crafts Education

\section{Giriş}

Bireysel ve toplumsal eğitimin vazgeçilmez parçalarından biri olan sanat eğitimi dünyayı doğru anlama ve anlamlandırmayı sağlar. Özgür ve özgün düşünme öncelikle duyuların eğitilmesiyle; düşünme ve algılama ile akı1 ve duyuların karşılıklı etkileşimi sayesinde gerçekleşebilir. Duyuları eğitilmeyen kişiler çevrelerine yönelik ilgisiz ve sorunlara karşı duyarsız tutum gösterir, sanat eğitimi en çok duyuların eğitimi için gereklidir (Şahin ve Yağçı, 2012, s. 275). Değişim içinde olan modern toplumların zihnin tasarısı olan sanat ve sanat eğitiminde, sorgulama, araştırma, düşünmeyi doğru kullanma, farkındalık sahibi olma gibi becerilerin kazandırılması ve yaratıcı, özgün ve özgüven sahibi kişilerin yetiştirilmesi amaçlanmıştır. Nitelikli sanat eğitiminin faktörlerinden biri öğrenme ve öğretmenin etkililiğidir. Öğrenme ve öğretmede bireysel farklılıklar sebebiyle öğrenciler birbirlerinden farklı ya da benzer şekillerde öğrenebilirken, öğrenen kişilerin bireysel farklılık durumuna ya da öğretenlerin bireysel 
tercihine göre bilginin etkili ve kalıcı olması için öğretim yöntemleri çeşitlilik ya da değişkenlik gösterebilir. $\mathrm{Bu}$ çeşitliliğin sebeplerinden biri de kişilerin birbirlerinden farklı düşünme becerilerine sahip olmasıdır.

Birçok araştırma neticesinde düşünme günümüze kadar çeşitli tanımlar ile gelmiş bir eylem olduğu söylenebilir. Düşünme ile ilgili yapılan ilk betimlemeler olayların içsel görünümü ve sunumu olarak belirtilmiş (Arkonaç, 1993, s. 27) fakat sonrasında insanlar için bu durumun yeterli olmadığı görülmüştür. Günümüzde düşünme ile ilgili çeşitli araştırmalar incelendiğinde, düşünme özetle, insanın belirli amaçlara ulaşma, durum tespit etme ve kavrama gibi hedefler doğrultusunda bilinçli ya da bilinçsiz yaptığı eylem olarak belirtilebilir. Her bireyin düşünme süreci birbirinden farklı olduğu gibi bu farklılıklar, bireylerin yeteneklerini farklı yollarla kullanmalarını ve farklı tepkiler vermelerini sağlarken, bireyler belirli durumlarda da benzer süreçleri kullanabilirler. Sternberg ve Lubart (1991, s. 4), bu durumu yeteneklerin kullanımında tercih edilen yol olarak tanımlar. Düşünme, bireylerin hangi durumlarda nasıl düşüneceği ya da hangi düşünme türünü kullanmayı tercih ettikleri stiller ile ilgilidir (Özer, 2016, s. 13). Stillerin, zekâ ya da yetenek değil, sahip olunan yetenekleri kullanmada tercih edilen yol olması önem taşır. Sternberg $(1999$, s. 8)'e göre stiller insanların neler yapmayı tercih ettiklerini yani sahip olunan yeteneklerden nasıl yararlandıklarını daha iyi anlamalarını sağlar, insanlarda sosyalleşme süreci ile kazanılır, yaşam süresi boyunca ya da zaman dilimine göre değişebilir, ölçülebilir ve öğretilebilir, ayrıca iyi ya da kötü olarak değil uygunluk olarak ayırt edici özelliğe sahiptir.

Sternberg; kültür, cinsiyet, yaş, anne ve babalık stilleri, okul eğitimi ve meslek gibi farklı değişkenlerin düşünme stillerinin gelişiminde etkili olabileceğini belirtir. Bireylerin, birbirlerinden farklı genetik yapıları, farklı bilgi birikimleri ve farklı yetişme ortamları sebebiyle düşünme stillerinin birbirinden farklı olduğu bilinmekle birlikte aynı değişkenlere sahip olmalarına karşın düşünme stillerinde yine farklılıklar görülebilir. Görülen bireysel farklılıklar sebebiyle, bireylerin başarılı oldukları ve olmadıkları alanlar farklılık gösterebilir. Ancak öğrencilerin kendi düşünme stillerinin farkında olması ve düşünme stillerini kullanma becerilerine sahip olması ile birlikte eğitimcilerin, öğrencilerin kullandığı düşünme stillerine göre geliştirecekleri öğretim yöntemleri sayesinde başarı sağlanabilir. Öğrencilerin günlük faaliyetlerini gerçekleştirirken ya da öğrenme süreçlerinde davranış kazanmaya çalışırken, becerilerini işe koşmak için tercih ettikleri yaklaşımlarını ve yöntemlerini (stillerini) bilmeleri ve açıklamaları, özellikle akademik alan başta olmak üzere her alanda performanslarını yükseltmeleri bakımından yararlı olacağı düşünülmektedir. Bu sebeple eğitsel gereksinimlerden biri de stil kavramına yönelik yeterli ve güçlü bir farkındalıktır. Araştırmalar bireylerin gerçekleştirdiği her etkinlikte düşünme stilinin etkili niteliğe sahip bir özellik olduğunu gösterir (Buluş, 2005, s. 4).

Öğrencilerin düşünme stillerini nasıl kullandıkları konusunda farkındalık sahibi olmaları, sistemli bir şekilde düşünme tercihlerini yönetmeleri ve geliştirmeleri, içinde yaşadığımız çağa uyum sağlayabilmeleri için önem taşır. Düşünme stillerinin ortaya çıkarılmasına yönelik geliştirilen çalışmalar, öğrencilerin kendi düşünme stillerini keşfetmeye sevk edecek, aynı zamanda öğretmen adayı olan öğrencilerin ileride çeşitli düşünme stillerine sahip öğrencilere verecekleri sanat eğitimi yöntemlerine (düşünme stillerini belirlenmesi buna ilişkin eğitim öğrt prog.) katk1 sağlayacağı düşünülmektedir. Kişilerin, dolayısıyla öğrencilerin düşünme stillerinde bireysel özellikler etki gösterir. Bu bilgiler doğrultusunda Güzel Sanatlar Eğitimi Bölümü öğrencilerinin düşünme stillerini belirlemek ve sosyo-demografik değişkenlere göre incelemek araştırmanın temel problemini oluşturmaktadır.

Sanat eğitiminin amaçlarına ve niteliğine yönelik gerçekleştirilecek çalışmaların öncelikli olarak Güzel Sanatlar Eğitimi Bölümlerinde öğrenim gören öğretmen adaylarıyla gerçekleştirilmesi ve bireysel farkındalıklarının artırılması şüphesiz önem taşımaktadır. Bu sebeple çalışmanın temel amacı Güzel Sanatlar Eğitimi Bölümü öğrencilerinin düşünme stillerini belirlemek ve belirlenen düşünme stilleri ile akademik not ortalamaları ve farklı değişkenler arasındaki ilişkiyi incelemektir. Bu amaç doğrultusunda aşağıdaki alt amaçlara cevap aranmıştır.

1. Güzel Sanatlar Eğitimi Bölümü öğrencilerinin düşünme stillerini kullanma düzeyleri nasıl bir dağıllım göstermektedir?

2. Güzel Sanatlar Eğitimi Bölümü öğrencilerinin düşünme stilleri ile öğrenim gördükleri bölüm arasında anlamlı bir farklılık var midır?

3. Güzel Sanatlar Eğitimi Bölümü ögrencilerinin düşünme stilleri ile mezun oldukları lise türü arasında anlamlı bir farklılık var midır?

4. Güzel Sanatlar Eğitimi Bölümü öğrencilerinin düşünme stilleri ile sınıfları arasında anlamlı bir farklılık var midir?

5. Güzel Sanatlar Eğitimi Bölümü öğrencilerinin düşünme stilleri ile cinsiyetleri arasında anlamlı bir farklılık var midır?

6. Güzel Sanatlar Eğitimi Bölümü öğrencilerinin düşünme stilleri ile yaşları arasında anlamlı bir farklılık var midir?

7. Güzel Sanatlar Eğitimi Bölümü öğrencilerinin düşünme stilleri ile sanatsal, kültürel ve sportif etkinlikleri uygulama durumları arasında anlamlı bir farklılık var midır? 
8. Güzel Sanatlar Eğitimi Bölümü öğrencilerinin düşünme stilleri ile akademik not ortalamaları arasında anlamlı bir ilişki var mıdır?

\section{Yöntem}

Bu araştırma tarama modelinde betimsel bir çalışmadır. Araştırmada Çanakkale Onsekiz Mart Üniversitesi Eğitim Fakültesinin Güzel Sanatlar Eğitimi Müzik Eğitimi ve Resim-İş Eğitimi Anabilim Dallarında öğrenim gören öğrencilerin düşünme stilleri belirlenerek farklı değişkenler (yaş, cinsiyet, sınıf, bölüm, mezun olunan lise türü ve sanatsal, kültürel, sportif etkinlikleri uygulama durumu) açısından incelendiği için ilişkisel tarama modelindedir. Tarama modeli geçmişte ya da halen var olan durumu betimlemeyi amaçlar. Araştırmaya konu olan olay, nesne ya da bireyler kendi koşulları doğrultusunda tanımlanmaya çalışılır (Karasar, 2012, s. 77). İlişkisel tarama modeli ise ilişkisel çözümleme, korelasyon türü ilişkiler ya da karşılaştırma yolu ile elde edilen ilişkilerdir (Karasar, 1995, s. 81).

\section{1. Çalışma Grubu}

Bu araştırmanın çalışma grubunu, 2018-2019 eğitim öğretim yılında Çanakkale Onsekiz Mart Üniversitesi Eğitim Fakültesi, Müzik Eğitimi ve Resim-İş Eğitimi Anabilim Dallarına kayıtlı olan ve öğretim elemanlarıyla yapılan görüşmeler sonucunda bölümlere bu dönem içerisinde devam ettiği tespit edilmiş olan öğrenciler oluşturmaktadır.

Tablo 1

Araştırmaya Katılan Öğrencilerin Cinsiyete Göre Dağılımları

\begin{tabular}{cccc}
\hline Cinsiyet & f & \% \\
\hline Erkek & 52 & 35.6 \\
Kadin & 94 & 64.4 \\
Toplam & 146 & 100 \\
\hline
\end{tabular}

Çalışma grubunu oluşturan öğrencilerin 25’i (\%17,1) 17-19, 72’si (\%49,3) 20-22, 49'u (\%33,6) 23 ve üstü yaş grubundadır. Öğrencilerin 23’ü (\%15,8) 1. sınıfta, 25'i (\%17,1) 2. sinıfta, 41 'i (\%28,1) 3. sınıfta, 57'si (\%39,0) 4. sınıfta eğitim görmektedir. 86'sı $(\% 58,9)$ müzik öğretmenliği bölümünde, $60(\% 41,1)$ resim-iş öğretmenliği bölümünde öğrenim görmektedir. Öğrencilerin mezun oldukları lise türlerine göre $73(\% 50,0)$ Güzel Sanatlar Lisesi, 29 (\%19,9) Anadolu Lisesi, 32 (\%21,9) Meslek Lisesi, 12 (\%8,2) Genel Lise şeklinde bir dağılım görülmüştür. Öğrecilerden 126 'sında $(\% 86,3)$ aile gelir düzeyi orta ve üzeridir. Çalışmada öğrencilerin 48'inin $(\% 32,9)$ anne öğrenim durumu ve 65 'inin $(\% 44,5)$ baba öğrenim durumu ortaöğretim düzeyindedir.

\subsection{Verilerin Toplanması}

$\mathrm{Bu}$ araştırmanın verileri, araştırmaya katılan Güzel Sanatlar Eğitimi Bölümü öğrencilerinin sosyo-demografik ve öğrenim durumu özelliklerini tespit etmek amacıyla araştırmacı tarafından oluşturulan kişisel bilgi formu ve düşünme stillerini tespit etmek için ise Sternberg ve Wagner (1992) tarafından geliştirilen ve Türkçe geçerlik ve güvenirlik çalışması Buluş (2006) tarafından yapılmış olan “Düşünme Stilleri Ölçeği”” uygulanarak elde edilmiştir. Düşünme Stilleri Ölçeği fonksiyonlarına (yasama, yürütme, yargı), biçimlerine (monarşik, hiyerarşik, oligarşik, anarşik), seviyelerine (global, lokal), alanlarına (içsel, dışsal) ve eğilimlerine (liberal, muhafazakâr) göre olmak üzere 5 temel boyut ve 13 alt boyuttan; her alt boyut 5 maddeden oluşmaktadır. 65 sorudan oluşan ve likert tipinde geliştirilen ölçeğe; 1 bana hiç uygun değil, 2 bana pek uygun değil, 3 bana çok az uygun, 4 puan bana biraz uygun, 5 bana oldukça uygun, 6 bana çok uygun, 7 tamamen bana uygun şeklinde puanlanmıştır. Araştırmaya dahil edilen ve öğrencilerin akademik başarılarını gösterdiği varsayılan güz dönemi not ortalamaları Çanakkale Onsekiz Mart Üniversitesi Eğitim Fakültesi öğrenci işlerinden temin edilmiştir.

Araştırmada kullanılan ve Zihinsel Benlik-Yönetimi Kuramı doğrultusunda hazırlanan Düşünme Stilleri Ölçeği, Sternberg ve Wagner tarafından 1992 yılında geliştirilmiş, Türkçe geçerlik ve güvenirlik çalışması Buluş (2006) tarafindan yapılan çalışma ile toplanmıştır. Ölçek 5 temel boyut ve 13 alt boyut olmak üzere; her alt boyut 5 maddeden oluşmaktadır. 65 sorudan oluşan ve likert tipinde geliştirilen ölçeğe; 1 bana hiç uygun değil, 2 bana pek uygun değil, 3 bana çok az uygun, 4 puan bana biraz uygun, 5 bana oldukça uygun, 6 bana çok uygun, 7 tamamen bana uygun şeklinde puanlanmıştır. Ölçekte bulunan boyutlar sırasıyla fonksiyonlarına göre; yasama düşünme stili (1,2,3,4,5. maddeler), Yürütme Düşünme Stili $(6,7,8,9,10$. maddeler) yargı düşünme stili $(11,12,13,14,15$. Maddeler), biçimlerine göre; monarşik düşünme stili $(16,17,18,19,20$. maddeler), hiyerarşik düşünme stili $(21,22,23,24,25$. maddeler), oligarşik düşünme stili $(26,27,28,29,30$. maddeler), anarşik düşünme stili (31,32,33,34,35. maddeler), seviyelerine göre; global düşünme stili (36,37,38,39,40. maddeler), lokal düşünme stili (41,42,43,44,45. maddeler), alanlarına göre; içsel düşünme stili (46,47,48,49,50. maddeler), dışsal düşünme stili (51,52,53,54,55. maddeler), eğilimlerine göre; liberal düşünme stili (56,57,58,59,60. maddeler), muhafazakar düşünme stili $(61,62,63,64,65$. maddeler) şeklindedir. 


\subsection{Verilerin Analizi}

Çalışmada verilerin analizinde SPSS 23. (IBM) paket programı kullanılmıştır. Tanımlayıcı istatistiklerin oluşturulmasında sayı, yüzde, en küçük, en büyük değerler, standart sapma ve ortalama, ortanca gibi merkezi ve yaygınlık ölçütleri kullanılmıştır. Sayısal değişkenlerin normal dağılıma uygunluğu görsel (histogram) ve analitik (Shapiro-Wilk) olarak test edilmiş ve normal dağılım kuramına uyan bağımsız değişkenler arasındaki farkın saptanmasında ANOVA ve t testleri, normal dağılım kuramına uymayan bağımsız değişkenler arasındaki farkın tespitinde ise Kruskal Wallis ve Mann Whitney U testleri kullanılmıştır. Sayısal değikenler arasındaki korelasyonların belirlenmesinde ise Pearson Korelasyon Testinden yararlanılmıştır. Çalışmada p değerinin 0,05'in altında olması anlamlı kabul edilmiştir.

\section{Bulgular}

\subsection{Birinci Alt Amaca Yönelik Bulgular}

Araştırmanın “Güzel Sanatlar Eğitimi Bölümü öğrencilerinin düşünme stillerini kullanma düzeyleri nasıl bir dağılım göstermektedir?" şeklinde ifade edilen birinci alt problemine yönelik incelemede, öğrencilerin kullandıkları düşünme stillerinin nasıl bir dağılım gösterdiğini belirlemek amacıyla düşünme stilleri puanlarının ortalama ve standart sapma değerleri hesaplanmış, bulgular Tablo 2'de gösterilmiştir.

Tablo 2

Öğrencilerin Düşünme Stillerini Kullanma Düzeylerine İlişkin Dağılımları

\begin{tabular}{|c|c|c|c|}
\hline Düșünme Stilleri & $\mathbf{N}$ & $\overline{\mathbf{X}}$ & Ss \\
\hline Yasama Düşünme Stili & 146 & 5.82 & 1.063 \\
\hline Liberal Düşünme Stili & 146 & 5.32 & 1.247 \\
\hline Yarg1 Düşünme Stili & 146 & 5.22 & 1.302 \\
\hline Hiyerarşik Düşünme Stili & 146 & 5.20 & 1.349 \\
\hline İçsel Düşünme Stili & 146 & 5.12 & 1.377 \\
\hline Yürütme Düşünme Stili & 146 & 5.10 & 1.169 \\
\hline Anarşik Düşünme Stili & 146 & 4.78 & 1.343 \\
\hline Dişsal Düşünme Stili & 146 & 4.72 & 1.383 \\
\hline Lokal Düşünme Stili & 146 & 4.66 & 1.358 \\
\hline Oligarşik Düşünme Stili & 146 & 4.56 & 1.372 \\
\hline Monarşik Düşünme Stili & 146 & 4.51 & 1.065 \\
\hline Global Düşünme Stili & 146 & 4.29 & 1.498 \\
\hline Muhafazakâr Düșünme Stili & 146 & 3.93 & 1.705 \\
\hline
\end{tabular}

Tablo 2 incelendiğinde araştırmaya katılan öğrencilerin sırasıyla yasama $(\overline{\mathrm{X}}=5,82)$, liberal $(\overline{\mathrm{X}}=5,32)$, yarg1 $(\bar{X}=5,22)$, hiyerarşik $(\bar{X}=5,20)$, içsel $(\bar{X}=5,12)$, yürütme $(\bar{X}=5,10)$, anarşik $(\bar{X}=4,78)$, dişsal $(\bar{X}=4,72)$, lokal $(\bar{X}=4,66)$, oligarşik $(\bar{X}=4,56)$ monarşik $(\bar{X}=4,51)$, global $(\bar{X}=4,29)$ düşünme stillerini, en az ise muhafazakâr $(\overline{\mathrm{X}}=3,93)$ düşünme stilini kullandıkları tespit edilmiştir.

\section{2. İkinci Alt Amaca Yönelik Bulgular}

Araştırmanın “Güzel Sanatlar Eğitimi Bölümü öğrencilerinin düşünme stilleri ile öğrenim gördükleri bölüm arasında anlamlı bir farklılık var mıdır?" şeklinde ifade edilen ikinci alt problemine yönelik incelemede, öğrencilerin düşünme stilleri ile bölüm değişkenine göre anlam bir farklılık gösterip göstermediğini belirlemek amacıyla t-testi analizi uygulanmış, bulgular Tablo 3 'te gösterilmiştir.

Tablo 3

Öğrencilerin Bölümlerine Göre Düşünme Stilleri Puanlarının Karşılaştırılması

\begin{tabular}{|c|c|c|c|c|c|c|}
\hline \multirow[b]{3}{*}{ Düșünme Stilleri } & \multicolumn{4}{|c|}{ Bölüm } & \multirow[b]{3}{*}{$\mathbf{t}$} & \multirow[b]{3}{*}{$\mathbf{p}^{*}$} \\
\hline & \multicolumn{2}{|c|}{ Resim İş Öğretmenliği (n=60) } & \multicolumn{2}{|c|}{ Müzik Öğretmenliği (n=86) } & & \\
\hline & Ort & SS & Ort & SS & & \\
\hline Yasama & 5.9 & 1.0 & 5.7 & 1.1 & 1.1 & 0.30 \\
\hline Yürütme & 5.0 & 1.0 & 5.2 & 1.3 & -0.9 & 0.38 \\
\hline Yarg1 & 5.3 & 1.2 & 5.2 & 1.4 & 0.8 & 0.45 \\
\hline Monarşik & 4.5 & 0.9 & 4.5 & 1.2 & 0.1 & 0.99 \\
\hline Hiyerarşik & 5.4 & 1.3 & 5.1 & 1.4 & 1.2 & 0.24 \\
\hline Oligarşik & 4.7 & 1.3 & 4.5 & 1.5 & 0.7 & 0.48 \\
\hline Anarşik & 4.8 & 1.2 & 4.7 & 1.4 & 0.5 & 0.66 \\
\hline Global & 4.2 & 1.6 & 4.4 & 1.5 & -0.8 & 0.40 \\
\hline Lokal & 4.7 & 1.3 & 4.7 & 1.4 & -0.1 & 0.93 \\
\hline İçsel & 5.3 & 1.2 & 5.0 & 1.5 & 1.1 & 0.29 \\
\hline Dişsal & 4.7 & 1.3 & 4.8 & 1.5 & -0.5 & 0.60 \\
\hline Liberal & 5.6 & 1.1 & 5.2 & 1.3 & 2.0 & 0.05 \\
\hline Muhafazakâr & 3.8 & 1.7 & 4.1 & 1.7 & -1.1 & 0.29 \\
\hline
\end{tabular}


Bu bulgulara göre araştırmada bölümler arasında düşünme stilleri açısından anlamlı bir fark tespit edilmemiştir $(\mathrm{p}>0,05)$. Bu durum, araştırmanın uygulandığı programların her ikisinin de sanat eğitimi bölümü olmasından kaynaklanabilir. Farklı bölümlerde sonuç farklılık gösterebilir.

\section{3. Üçüncü Alt Amaca Yönelik Bulgular}

Araştırmanın "Güzel Sanatlar Eğitimi Bölümü öğrencilerinin düşünme stilleri ile mezun oldukları lise türü arasında anlamlı bir farklılık var mıdır?" alt problemine yönelik inceleme, Kruskal Wallis Testi analizi uygulanarak yapılmıştır. Bulgular Tablo 4’te verilmiştir.

Tablo 4

Öğrencilerin Mezun Oldukları Lise Türüne Göre Düşünme Stilleri Puanlarının Karşılaştırılması

\begin{tabular}{|c|c|c|c|c|c|c|}
\hline \multicolumn{7}{|c|}{ Mezun Olunan Lise Türü } \\
\hline \multirow[b]{2}{*}{ Düşünme Stilleri } & Güzel Sanatlar $(n=73)$ & Anadolu Lisesi $(n=29)$ & Meslek Lisesi $(n=32)$ & Genel Lise $(n=12)$ & \multirow{2}{*}{$\mathbf{K W}$} & \multirow{2}{*}{$p^{*}$} \\
\hline & Med (Min/Max) & Med (Min/Max) & Med (Min/Max) & Med (Min/Max) & & \\
\hline Yasama & $6(2.2 / 7)$ & $6.2(3.4 / 7)$ & $6(3.2 / 7)$ & $5.9(2.6 / 7)$ & 0.2 & 0.98 \\
\hline Yürütme & $5.4(2.8 / 7)$ & $5(1.4 / 7)$ & $5.5(3.6 / 6.8)$ & $5(3.2 / 7)$ & 3.5 & 0.33 \\
\hline Yarg1 & $5.4(2.2 / 7)$ & $5.2(1.6 / 7)$ & $5.1(3.6 / 7)$ & $5(3.8 / 7)$ & 0.4 & 0.95 \\
\hline Monarşik & $4.6(2.6 / 6.8)$ & $4.6(1.6 / 6)$ & $4.4(1.8 / 6.4)$ & $4.4(3 / 6.4)$ & 0.7 & 0.87 \\
\hline Hiyerarşik & $5.4(1 / 7)$ & $5.4(1.8 / 7)$ & $5.7(3.4 / 7)$ & $4.7(2.8 / 7)$ & 2.2 & 0.52 \\
\hline Oligarşik & $4.4(1 / 7)$ & $5.2(1.4 / 7)$ & $4.9(2.4 / 7)$ & $4.2(1 / 6.2)$ & 4.1 & 0.25 \\
\hline Anarşik & $4.8(2 / 7)$ & $5.4(2.2 / 7)$ & $4.4(2.4 / 6.8)$ & $5.2(1.8 / 6.8)$ & 1.9 & 0.59 \\
\hline Global & $4.4(1 / 7)$ & $4.2(1 / 7)$ & $4.3(1 / 6.6)$ & $4.4(1 / 6.4)$ & 0.8 & 0.85 \\
\hline Lokal & $4.6(2.2 / 7)$ & $4.8(2.2 / 7)$ & $4.5(2.4 / 7)$ & $5.1(2.2 / 6.4)$ & 0.6 & 0.89 \\
\hline İçsel & $5.4(1.8 / 7)$ & $5.6(1.4 / 7)$ & $5.4(2.8 / 7)$ & $4.4(2 / 7)$ & 1.4 & 0.71 \\
\hline Dişsal & $5(1.6 / 6)$ & $4.4(1.8 / 7)$ & $4.6(2.2 / 6.6)$ & $4.1(1 / 6.6)$ & 3.4 & 0.33 \\
\hline Liberal & $5.4(1.4 / 7)$ & $5.4(2.8 / 7)$ & $5.6(3.2 / 7)$ & $5.8(3.6 / 7)$ & 1.2 & 0.75 \\
\hline Muhafazakâr & $4(1 / 7)$ & $4.4(1 / 7)$ & $3.4(1 / 6.4)$ & $3.4(1 / 6.2)$ & 1.8 & 0.61 \\
\hline
\end{tabular}

Tablo 4'te verilen bulgulara göre, mezun olunan lise türleri ile düşünme stilleri arasındaki ilişkisel analiz sonucunda $\mathrm{p}$ değerlerinin 0,05 değerinden yüksek olduğu görülmüş, anlamlı farklılık olmadığı saptanmıştır. Bu durum sanat eğitimi gören öğrencilerin önceki eğitimlerinin düşünme stilleri üzerinde etkili olmadığı şeklinde izah edilebilir.

\subsection{Dördüncü Alt Amaca Yönelik Bulgular}

Araştırmanın "Güzel Sanatlar Eğitimi Bölümü öğrencilerinin düşünme stilleri ile sınıfları arasında anlamlı bir farklılık var mıdır?” şeklinde ifade edilen üçüncü alt problemine yönelik incelemede, öğrencilerin düşünme stilleri puanları ile sınıf değişkeni arasında anlamlı bir farklılık olup olmadığını belirlemek amacıyla Kruskal Wallis Testi uygulanmış, bulgular Tablo 5 'te verilmiştir.

Tablo 5

Öğrencilerin Sınıflarına Göre Düşünme Stilleri Puanlarının Karşılaştırılması

\begin{tabular}{|c|c|c|c|c|c|c|}
\hline \multicolumn{7}{|c|}{ Sinıf } \\
\hline & 1. Sinıf $(n=23)$ & 2. Sinıf $(n=25)$ & 3. Sinıf $(n=41)$ & 4. Sinıf $(n=57)$ & & \\
\hline Düşünme Stilleri & Med (Min/Max) & Med (Min/Max) & Med (Min/Max) & Med (Min/Max) & $\mathbf{K W}$ & p* \\
\hline Yasama & $6.4(3.4 / 7)$ & $6.2(2.2 / 7)$ & $6.2(3 / 7)$ & $6(2.6 / 7)$ & 3.6 & 0.31 \\
\hline Yürütme & $5.6(1.4 / 7)$ & $5.4(3.2 / 6.8)$ & $4.8(3 / 7)$ & $5.4(2.8 / 7)$ & 3.6 & 0.31 \\
\hline Yarg1 & $5.8(1.8 / 7)$ & $6(3.6 / 7)^{\mathrm{a}}$ & $5(1.6 / 7)^{b}$ & $5(2 / 7)^{\mathrm{b}}$ & 9.5 & 0.02 \\
\hline Monarşik & $5.2(1.6 / 6.4)$ & $4.2(2.8 / 6.8)$ & $4.6(2.2 / 6)$ & $4.6(3 / 6.6)$ & 2.8 & 0.42 \\
\hline Hiyerarşik & $5.6(1.8 / 7)$ & $5.8(2.2 / 7)$ & $5.4(2 / 7)$ & $5(1 / 7)$ & 2.4 & 0.49 \\
\hline Oligarşik & $5.2(1 / 7)$ & $4.2(2.2 / 7)$ & $5.2(1.4 / 7)$ & $4.2(1 / 7)$ & 6.4 & 0.09 \\
\hline Anarşik & $5(1.8 / 7)$ & $5.6(2.8 / 7)^{\mathrm{a}}$ & $5(2 / 7)$ & $4.6(2.2 / 7)^{\mathrm{b}}$ & 9.7 & 0.02 \\
\hline Global & $3.4(1 / 6.8)$ & $4(1.8 / 7)$ & $4.6(2 / 7)$ & $4.6(1 / 7)$ & 6.4 & 0.09 \\
\hline Lokal & $4.4(2.2 / 7)$ & $4.4(2.2 / 7)$ & $4.8(2.2 / 7)$ & $4.6(2.2 / 7)$ & 1.3 & 0.72 \\
\hline İçsel & $5.4(2 / 7)$ & $5.4(2.2 / 7)$ & $5.6(1.4 / 7)$ & $5.4(1.8 / 7)$ & 0.4 & 0.94 \\
\hline Dişsal & $4(1 / 6.6)$ & $4.6(2 / 6.8)$ & $5(1.6 / 7)$ & $4.8(1.6 / 7)$ & 2.0 & 0.56 \\
\hline Liberal & $5.2(2.8 / 7)$ & $5.8(3.8 / 7)$ & $5.6(3.2 / 7)$ & $5.4(1.4 / 7)$ & 3.6 & 0.31 \\
\hline Muhafazakâr & $3.6(1 / 6.4)$ & $3(1 / 7)$ & $4.6(1 / 7)$ & $4(1 / 7)$ & 7.6 & 0.06 \\
\hline
\end{tabular}

Tablo 5 'te görülen bulgulara göre araştırmada sınıflar arasında yargı ve anarşik düşünme stilleri arasında anlamlı bir fark saptanmıştır $(p=0,02)$. 2. sınıf öğrencilerinin yargı ve anarşik düşünme stili puanlarının 3. ve 4. sınıfların puanlarına göre anlamlı seviyede fazla olduğu saptanmıştır. Çalışmada sınıflar arasında diğer düşünme stilleri açısından anlamlı bir fark tespit edilmemiştir ( $p>0,05)$. 


\subsection{Beşinci Alt Amaca Yönelik Bulgular}

Araştırmanın "Güzel Sanatlar Eğitimi Bölümü öğrencilerinin düşünme stilleri ile cinsiyetleri arasında anlamlı bir farklılık var mıdır?" şeklinde ifade edilen dördüncü alt problemine yönelik incelemede, öğrencilerin düşünme stillerinde cinsiyetlerine göre anlamlı farklılık olup olmadığını tespit etmek amacıyla t-testi analizi kullanılmıştır. Bulgular Tablo 6'da verilmiştir.

Tablo 6

Öğrencilerin Cinsiyetlerine Göre Düşünme Stilleri Puanlarının Karşılaştırılması

\begin{tabular}{|c|c|c|c|c|c|c|}
\hline \multirow[b]{3}{*}{ Düșünme Stilleri } & \multicolumn{4}{|c|}{ Cinsiyet } & \multirow[b]{3}{*}{$\mathbf{t}$} & \multirow[b]{3}{*}{$\mathbf{p}^{*}$} \\
\hline & \multicolumn{2}{|c|}{ Erkek $(n=52)$} & \multicolumn{2}{|c|}{ Kadın $(n=94)$} & & \\
\hline & Ort & SS & Ort & SS & & \\
\hline Yasama & 5.8 & 1.1 & 5.8 & 1.1 & 0.1 & 0.99 \\
\hline Yürütme & 5.1 & 1.1 & 5.1 & 1.2 & -0.1 & 0.94 \\
\hline Yarg1 & 5.1 & 1.4 & 5.3 & 1.2 & -0.8 & 0.43 \\
\hline Monarşik & 4.6 & 1.1 & 4.5 & 1.1 & 0.4 & 0.70 \\
\hline Hiyerarşik & 5.0 & 1.4 & 5.3 & 1.3 & -1.5 & 0.13 \\
\hline Oligarşik & 4.8 & 1.3 & 4.4 & 1.4 & 1.8 & 0.07 \\
\hline Anarşik & 5.0 & 1.2 & 4.7 & 1.4 & 1.2 & 0.23 \\
\hline Global & 4.4 & 1.4 & 4.2 & 1.6 & 0.9 & 0.38 \\
\hline Lokal & 4.6 & 1.3 & 4.7 & 1.4 & -0.7 & 0.48 \\
\hline İçsel & 5.1 & 1.5 & 5.1 & 1.3 & 0.1 & 0.99 \\
\hline Dişsal & 4.8 & 1.3 & 4.7 & 1.4 & 0.3 & 0.74 \\
\hline Liberal & 5.2 & 1.2 & 5.4 & 1.3 & -1.2 & 0.24 \\
\hline Muhafazakâr & 4.2 & 1.5 & 3.8 & 1.8 & 1.6 & 0.11 \\
\hline
\end{tabular}

Tablo 6'da verilen bulgulara göre, cinsiyet değişkeni ile düşünme stilleri arasındaki ilişkisel analiz sonucunda $\mathrm{p}$ değerlerinin 0,05 değerinden yüksek olduğu görülmüş, anlamlı bir farklılık olmadığı saptanmıştır. Bu bulgulara göre çalışma grubunun düşünme stilleri ile cinsiyetleri arasında anlamlı bir farklılık söz konusu değildir.

\subsection{Altıncı Alt Amaca Yönelik Bulgular}

Araştırmanın "Güzel Sanatlar Eğitimi Bölümü öğrencilerinin düşünme stilleri ile yaşları arasında anlamlı bir farklılık var mıdır?” şeklinde ifade edilen beşinci alt problemine yönelik incelemede, öğrencilerin yaşları ile düşünme stilleri puanları anlamlı farklılık olup olmadığı, Kruskal Wallis Testi analizi yapılarak incelenmiş, bulgular Tablo 7'de verilmiştir.

Tablo 7

Öğrencilerin Yaşlarına Göre Düşünme Stilleri Puanlarının Karşılaştırılması

\begin{tabular}{|c|c|c|c|c|c|}
\hline \multicolumn{6}{|c|}{ Yaş Grupları } \\
\hline \multirow[b]{2}{*}{ Düşünme Stilleri } & $17-19(n=25)$ & $20-22(n=72)$ & 23 ve üzeri $(n=49)$ & \multirow{2}{*}{ KW } & \multirow[b]{2}{*}{$\mathbf{p}^{*}$} \\
\hline & Med (Min/Max) & Med (Min/Max) & Med (Min/Max) & & \\
\hline Yasama & $6.4(2.2 / 7)$ & $6.1(2.6 / 7)$ & $6(3 / 7)$ & 2.7 & 0.26 \\
\hline Yürütme & $5.6(1.4 / 6.8)$ & $5.4(2.8 / 7)$ & $5(1.6 / 7)$ & 2.6 & 0.27 \\
\hline Yarg1 & $6.0(1.8 / 7)$ & $5.2(1.6 / 7)$ & $5(2 / 7)$ & 3.0 & 0.22 \\
\hline Monarşik & $4.6(1.6 / 6.4)$ & $4.5(2.2 / 6.6)$ & $4.6(1.8 / 6.8)$ & 0.3 & 0.87 \\
\hline Hiyerarşik & $5.6(1.8 / 7)$ & $5.4(2.2 / 7)$ & $5(1 / 7)$ & 2.0 & 0.37 \\
\hline Oligarşik & $5.0(2.4 / 7)$ & $4.6(1 / 7)$ & $4.4(2 / 7)$ & 1.1 & 0.57 \\
\hline Anarşik & $5.4(2.4 / 6.8)$ & $5.0(1.8 / 7)$ & $5(2 / 7)$ & 1.1 & 0.58 \\
\hline Global & $3.6(1 / 6.8)$ & $4.4(1 / 7)$ & $4.2(1 / 7)$ & 0.9 & 0.63 \\
\hline Lokal & $4.2(2.4 / 7)$ & $4.8(2.2 / 7)$ & $4.8(2.2 / 7)$ & 0.3 & 0.84 \\
\hline İçsel & $5.4(2.4 / 7)$ & $5.5(1.4 / 7)$ & $5.6(1.8 / 7)$ & 0.1 & 0.98 \\
\hline Dışsal & $4.6(2 / 6.8)$ & $5.0(1 / 7)$ & $4.8(1.6 / 7)$ & 0.4 & 0.83 \\
\hline Liberal & $5.6(3.8 / 7)$ & $5.6(2.8 / 7)$ & $5.2(1.4 / 7)$ & 5.6 & 0.06 \\
\hline Muhafazakâr & $3.4(1 / 6.4)$ & $3.9(1 / 7)$ & $4(1 / 7)$ & 2.4 & 0.30 \\
\hline
\end{tabular}

Tablo 7'de yer verilen bulgulara göre yaş grupları ile düşünme stilleri arasındaki ilişkisel analiz sonucunda $\mathrm{p}$ değerlerinin 0,05 değerinden düşük olmadığ 1 görülmüştür. Bu bulgulara göre araştırmada düşünme stilleri ile yaş değişkeni arasında anlamlı farklılık olmadığ 1 tespit edilmiştir.

\subsection{Yedinci Alt Amaca Yönelik Bulgular}

Araştırmanın "Güzel Sanatlar Eğitimi Bölümü öğrencilerinin düşünme stillerin ile sanatsal, kültürel ve sportif etkinlikleri uygulama durumları arasında anlamlı bir farklılık var mıdır?" şeklinde ifade edilen onuncu alt problemine yönelik incelemede, öğrencilerin tiyatroya gitme, konsere gitme sergiye gitme, sinemaya gitme, spor 
yapma, gazete okuma ve kültürel dergi okuma durumları ile düşünme stilleri arasında anlamlı fark olmadığı Mann Whitney U Testi uygulanarak analiz edilmiş, bulgular Tablo 8, 9 ve 10'da belirtilmiştir.

Tablo 8

Öğrencilerin Tiyatroya Gitme Durumuna Göre Düşünme Stillerinin Karşılaştırılması

\begin{tabular}{|c|c|c|c|c|c|c|}
\hline \multirow{3}{*}{ Düşünme Stilleri } & \multicolumn{4}{|c|}{ Tiyatroya Gitme Durumu } & \multirow{3}{*}{$\mathbf{Z}$} & \multirow{3}{*}{$p^{*}$} \\
\hline & \multicolumn{2}{|c|}{ Hiç $(n=51)$} & \multicolumn{2}{|c|}{$\operatorname{En} \operatorname{Az} 1 \operatorname{Kez}(n=95)$} & & \\
\hline & Med & Min/Max & Med & Min/Max & & \\
\hline Yasama & 6 & $2.2 / 7.0$ & 6.0 & $2.6 / 7.0$ & -0.1 & 0.93 \\
\hline Yürütme & 5 & $1.4 / 7.0$ & 5.4 & $1.6 / 7.0$ & -1.7 & 0.08 \\
\hline Yarg1 & 5 & $1.6 / 7.0$ & 5.4 & $2.2 / 7.0$ & -2.3 & 0.02 \\
\hline Monarşik & 4.4 & $1.6 / 6.2$ & 4.6 & $1.8 / 6.8$ & -1.5 & 0.14 \\
\hline Hiyerarşik & 5 & $1 / 7$ & 5.8 & $2.0 / 7.0$ & -2.1 & 0.04 \\
\hline Oligarşik & 4.2 & $1 / 7$ & 5.0 & $2.0 / 7.0$ & -2.0 & 0.05 \\
\hline Anarşik & 4.6 & $1.8 / 7$ & 5.2 & $2.2 / 7.0$ & -1.2 & 0.21 \\
\hline Global & 4.2 & $1 / 7$ & 4.4 & $1.0 / 7.0$ & -0.3 & 0.79 \\
\hline Lokal & 4.6 & $2.2 / 7$ & 4.6 & $2.2 / 7.0$ & -0.5 & 0.60 \\
\hline İçsel & 5.6 & $1.4 / 7$ & 5.4 & $1.8 / 7.0$ & -0.8 & 0.42 \\
\hline Dişsal & 4.4 & $1 / 7$ & 5.0 & $1.6 / 7.0$ & -1.6 & 0.12 \\
\hline Liberal & 5.4 & $1.6 / 7$ & 5.6 & $1.4 / 7.0$ & -0.5 & 0.65 \\
\hline Muhafazakâr & 4.0 & $1 / 7$ & 3.6 & $1.0 / 7.0$ & -0.5 & 0.58 \\
\hline
\end{tabular}

Tablo 8'de öğrencilerin tiyatroya gitme durumuna göre düşünme stillerinin karşılaştırılmasına göre araştırmada tiyatroya en az $1 \mathrm{kez}$ gitmiş öğrencilerin yargı $(p=0,02)$ ve hiyerarşik $(p=0,04)$ düşünme stili puanları, hiç gitmeyenlere göre anlamlı düzeyde daha fazladır. Çalışmada tiyatroya gitme durumu değişkeni ile diğer düşünme stilleri arasındaki bulgulara bakıldığında ise p değerlerinin 0,05 değerinden düşük olmadığı görülmüş, anlamlı bir fark tespit edilmemiştir.

Tablo 9

Öğrencilerin Sergiye Gitme Durumuna Göre Düşünme Stillerinin Karşılaştırılması

\begin{tabular}{|c|c|c|c|c|c|c|}
\hline \multirow{3}{*}{ Düşünme Stilleri } & \multicolumn{4}{|c|}{ Sergiye Gitme Durumu } & \multirow{3}{*}{$\mathbf{Z}$} & \multirow{3}{*}{ p* } \\
\hline & \multicolumn{2}{|c|}{ Hiç $(n=41)$} & \multicolumn{2}{|c|}{ En Az 1 Kez $(n=105)$} & & \\
\hline & Med & Min/Max & Med & Min/Max & & \\
\hline Yasama & 6 & $2.2 / 7.0$ & 6.0 & $2.6 / 7.0$ & -1.4 & 0.17 \\
\hline Yürütme & 5 & $1.4 / 7.0$ & 5.4 & $1.6 / 7.0$ & -1.3 & 0.19 \\
\hline Yarg1 & 5 & $1.6 / 7.0$ & 5.4 & $2 / 7.0$ & -2.3 & 0.02 \\
\hline Monarşik & 4.6 & $1.6 / 6.2$ & 4.4 & $1.8 / 6.8$ & -1.1 & 0.26 \\
\hline Hiyerarşik & 4.8 & $1.8 / 7$ & 5.8 & $1.0 / 7.0$ & -2.8 & $<0.01$ \\
\hline Oligarşik & 4.2 & $1.4 / 7$ & 4.8 & $1.0 / 7.0$ & -1.8 & 0.08 \\
\hline Anarşik & 4.4 & $2 / 7$ & 5.2 & $1.8 / 7.0$ & -2.1 & 0.04 \\
\hline Global & 4.2 & $2 / 7$ & 4.4 & $1.0 / 7.0$ & -0.8 & 0.43 \\
\hline Lokal & 4 & $2.2 / 7$ & 4.8 & $2.2 / 7.0$ & -1.6 & 0.11 \\
\hline İçsel & 5 & $1.4 / 7$ & 5.6 & $1.8 / 7.0$ & -2.2 & 0.03 \\
\hline Dışsal & 4.4 & $1.6 / 7$ & 5.0 & $1 / 7.0$ & -1.3 & 0.19 \\
\hline Liberal & 4.6 & $2.4 / 7$ & 5.8 & $1.4 / 7.0$ & -3.4 & $<0.01$ \\
\hline Muhafazakâr & 4.0 & $1.2 / 7$ & 3.6 & $1.0 / 7.0$ & -0.3 & 0.75 \\
\hline
\end{tabular}

Tablo 9'da verilen öğrencilerin sergiye gitme durumuna göre düşünme stillerinin karşılaştırılmasına göre araştırmada sergiye en az $1 \mathrm{kez}$ gitmiş öğrencilerin yarg1 $(p=0,02)$, hiyerarşik $(p=0,01)$, anarşik $(p=0,04)$, içsel $(\mathrm{p}=0,03)$ ve liberal $(\mathrm{p}=0,01)$ düşünme stili puanları, hiç gitmeyenlere göre anlamlı düzeyde daha fazladır. Çalışmada sergiye gitme durumu değişkeni ile diğer düşünme stilleri arasında ise p değerlerinin 0,05 değerinin altında görülmemesi sebebiyle anlamlı bir fark kaydedilmemiştir ( $\mathrm{p}>0,05)$.

Tablo 10

Öğrencilerin Spor Yapma Durumuna Göre Düşünme Stillerinin Karşılaştırılması

\begin{tabular}{|c|c|c|c|c|c|c|}
\hline \multirow{3}{*}{ Düşünme Stilleri } & \multicolumn{4}{|c|}{ Spor Yapma Durumu } & \multirow[b]{3}{*}{$\mathbf{Z}$} & \multirow[b]{3}{*}{$\mathbf{p}^{*}$} \\
\hline & \multicolumn{2}{|c|}{ Hiç $(n=29)$} & \multicolumn{2}{|c|}{$\operatorname{En} \operatorname{Az} 1 \operatorname{Kez}(n=117)$} & & \\
\hline & Med & $\operatorname{Min} / \mathbf{M a x}$ & Med & $\operatorname{Min} / \mathbf{M a x}$ & & \\
\hline Yasama & 6 & $2.2 / 7.0$ & 6.0 & $3 / 7.0$ & -1.3 & 0.21 \\
\hline Yürütme & 4.8 & $1.4 / 7.0$ & 5.4 & $1.6 / 7.0$ & -1.9 & 0.05 \\
\hline Yarg1 & 5 & $1.6 / 7.0$ & 5.4 & $1.8 / 7.0$ & -1.6 & 0.10 \\
\hline Monarşik & 4.2 & $1.6 / 5.8$ & 4.6 & $1.8 / 6.8$ & -0.7 & 0.48 \\
\hline Hiyerarşik & 4.6 & $1 / 6.4$ & 5.8 & $1.8 / 7.0$ & -3.2 & $<0.01$ \\
\hline Oligarşik & 4.4 & $1 / 7$ & 4.8 & $1.0 / 7.0$ & -0.9 & 0.35 \\
\hline Anarşik & 4.2 & $1.8 / 7$ & 5.2 & $2 / 7.0$ & -1.8 & 0.07 \\
\hline Global & 4.2 & $1 / 7$ & 4.4 & $1.0 / 7.0$ & -0.1 & 0.91 \\
\hline Lokal & 3.8 & $2.2 / 7$ & 4.8 & $2.2 / 7.0$ & -2.2 & 0.03 \\
\hline İçsel & 5.2 & $1.4 / 7$ & 5.6 & $1.8 / 7.0$ & -1.4 & 0.15 \\
\hline Dişsal & 4.2 & $1 / 7$ & 5.0 & $1.6 / 7.0$ & -2.1 & 0.03 \\
\hline Liberal & 5.4 & $1.6 / 7$ & 5.6 & $1.4 / 7.0$ & -1.8 & 0.06 \\
\hline Muhafazakâr & 3.8 & $1 / 7$ & 3.8 & $1.0 / 7.0$ & -0.6 & 0.56 \\
\hline
\end{tabular}


Tablo 10'da yer verilen öğrencilerin spor yapma durumuna göre düşünme stillerinin karş1laştırılmasına göre araştırmada en az 1 kez spor yapmış öğrencilerde hiyerarşik $(p=0,03)$, lokal $(p=0,03)$ ve dışsal $(p=0,03)$ düşünme stili puanları, hiç yapmamışlara göre anlamlı düzeyde daha fazladır. Çalışmada spor yapma durumu ile diğer düşünme stilleri arasında ise anlamlı bir fark kaydedilmemiştir. Ayrıca araştırmada konsere gitme, sinemaya gitme, gazete okuma ve kültürel dergi okuma durumuna göre düşünme stilleri arasında anlamlı fark olup olmadığı incelenmiş ancak anlamlı bir fark kaydedilmemiştir $(\mathrm{p}>0,05)$.

\subsection{Sekinci Alt Amaca Yönelik Bulgular}

Güzel Sanatlar Eğitimi Bölümü öğrencilerinin düşünme stilleri ile akademik not ortalamaları arasında anlamlı olup olmadığına yönelik incelemede, ögrencilerin düşünme stilleri ile akademik not ortalamaları arasındaki ilişki korelasyon analizi yapılarak incelenmiş, bulgular Tablo 11'de verilmiştir.

Tablo 11

Öğrencilerde Not Ortalaması İle Düşünme Stillerinin Korelasyonu

\begin{tabular}{|c|c|c|}
\hline \multirow{2}{*}{ Düşünme Stilleri } & \multicolumn{2}{|c|}{ Not Ortalaması } \\
\hline & $\mathbf{R}$ & $\mathbf{P}$ \\
\hline Yasama & -0.1 & $>0.05$ \\
\hline Yürütme & -0.1 & $>0.05$ \\
\hline Yarg1 & 0.10 & $>0.05$ \\
\hline Monarşik & 0.02 & $>0.05$ \\
\hline Hiyerarşik & 0.16 & $>0.05$ \\
\hline Oligarşik & 0.01 & $>0.05$ \\
\hline Anarşik & 0.04 & $>0.05$ \\
\hline Global & 0.02 & $>0.05$ \\
\hline Lokal & 0.01 & $>0.05$ \\
\hline İçsel & 0.10 & $>0.05$ \\
\hline Dıșsal & 0.04 & $>0.05$ \\
\hline Liberal & 0.13 & $>0.05$ \\
\hline Muhafazakâr & -0.12 & $>0.05$ \\
\hline
\end{tabular}

Tablo 11'de öğrencilerde not ortalaması ile düşünme stillerinin korelasyonu incelenmiş ancak anlamlı bir korelasyon saptanmamıştır $(\mathrm{p}>0,05)$.

\section{Sonuç ve Tartışma}

Birinci alt amaç doğrultusunda, araştırmada Güzel Sanatlar Eğitimi Bölümü öğrencilerinin düşünme stillerinin gösterdiği dağılım incelendiğinde, öğrencilerin sırasıyla en çok yaratıcılık ve yenilikçiliği temsil eden yasama, liberal ve yargısal düşünme stillerini kullanmayı tercih ettikleri, en az ise muhafazakâr, global ve monarşik düşünme stillerini kullandıkları tespit edilmiştir. Öğrencilerin en çok yasama stilini tercih ediyor olması, yaratıcı ve yenilikçi özelliğe sahip olduklarını göstermektedir. Araştırmada en çok yasama, en az ise muhafazakâr stilin tercih edildiğini gösteren bulgu, müzik eğitimi alan öğrenciler ile gerçekleştirilen Akçay (2019)'ın çalışması ve müzik bölümü öğrencileri ile gerçekleştirilen yine Akçay (2018a)'ın ve Akbulut (2006)'un çalışması ile aynı sonucu göstermektedir. Genel anlamda incelendiğinde ise eğitim fakültelerinin farklı bölümlerinde öğrenim görmekte olan öğrenciler ile gerçekleştirilen Dinçer (2009), Değirmenci, Kurt, Akıncı ve Orhon (2017), Akınc1, Kurt, Değirmenci ve Orhon (2017), Uyanık (2017), Saracaloğlu, Yenice ve Karasakaloğlu (2008), Tortop, Çalışkan ve Dinçer (2012), Buluş (2005) ve Çubukçu (2004)'nun çalışması, farklı fakültelerin farklı bölümlerinde uygulanan çalışmalardan Varol, Ertürk ve Dursun (2014)'un çalışması, lise öğrencileri ile gerçekleştirilen Merdin (2010)'in çalışması ve öğretmenler ile uygulanan çalışmalardan Akçay (2018b), Tüzer (2016) ve Oflar (2010)'ın çalışması bu araştırmanın birinci bulgusu ile benzerlik göstermektedir.

İkinci alt amaca yönelik olarak, Güzel Sanatlar Eğitimi Bölümü öğrencilerinin düşünme stilleri ile öğrenim gördükleri programlar arasında anlamlı farklılık olup olmadığının incelenmesi sonucunda Güzel Sanatlar Eğitimi Bölümü Resim-İş Öğretmenliği ve Müzik Öğretmenliği Anabilim Dallarında öğrenim görmekte olan öğrencilerin düşünme stilleri ile bölümleri arasında anlamlı farklılık görülmemiştir. Düşünme stillerinin bölüm değişkenine göre farklılaşmadığı bulgusu, yapılan benzer araştırmalardan Tortop, Çalışkan ve Dinçer (2012)'in çalışması ile benzerlik göstermekte ve araştırmayı destekler niteliktedir. Araştırmanın bu sorusuna yönelik, Buluş (2005), Dinçer (2009), Merdin (2010), Durdukoca (2011), Emir (2011), Uyanık (2017), Değirmenci, Kurt, Akıncı ve Orhon (2017), Akıncı, Kurt, Değirmenci ve Orhon, (2017) ve Saracaloğlu, Yenice ve Karasakaloğlu (2008) tarafından hazırlanan araştırmaların sonuçlarına göre düşünme stilleri ile öğrenim gördükleri bölümlere arasında anlamlı farklılık olduğu görülmektedir. Farklılık göstermeme sebebi olarak araştırmanın uygulandığı programların her ikisinin de sanat eğitimi bölümü olduğu düşünülebilir. Buna göre Güzel Sanatlar Eğitimi Bölümü öğrencilerinin bölümlerine göre düşünme stillerinde göstermediği söylenebilir.

Araştırmanın üçüncü alt amacı kapsamında Güzel Sanatlar Eğitimi Bölümü öğrencilerinin düşünme stilleri ile mezun oldukları lise türü arasında anlamlı bir ilişki olmadığı görülmüştür. Düşünme stilleri ile mezun olunan lise 
türü değişkeni Akçay (2018a), Akçay (2019), Değirmenci, Kurt, Akıncı ve Orhon (2017) ve Saracaloğlu, Yenice ve Karasakaloğlu (2008) tarafindan yapılan araştırmaların sonucunda anlamlı farklılık gösterir. Bu araştırmada anlamlı fark bulunması bu çalışmaların tersine bir durum oluşturmaktadır. Bu araştırmanın sonucuna göre Güzel Sanatlar Eğitimi Bölümü öğrencilerinde mezun oldukları liselerin düşünme stillerine etkisi olmadığı söylenebilir.

Dördüncü alt amaç kapsamında, araştırmada Güzel Sanatlar Eğitimi Bölümü öğrencilerinin düşünme stilleri ile sınıfları arasında farklılık olup olmadığı incelenmiş, buna göre 2. sınıf öğrencilerinin yargısal ve anarşik düşünme stilini, 3. ve 4. sınıflara göre anlamlı düzeyde daha fazla kullandığı tespit edilmiştir. 2. sınıf öğrencilerinin yarg1 ve anarşik düşünme stilini daha çok tercih etmeleri, öğrencilerin değerlendiren ve görüş belirten aynı zamanda prosedür ve kurallardan kaçınan kişilik özellikerine sahip olduklarını gösterir. Bu araştırmanın bulgularına yönelik öğrencilerin düşünme stilleri ile sınıfları arasında anlamlı farklılık olduğu sonucu, Dinçer (2009), Buluş (2005), Akçay (2019) Akıncı, Kurt, Değirmenci ve Orhon, (2017b), Tufan ve Coşkun (2009), Değirmenci, Kurt, Akıncı ve Orhon (2017), Varol, Ertürk ve Dursun (2014), Esmer (2013), Oflar (2010), Merdin (2010) ve Kaya (2009)'nın çalışmalarının sonuçlarını destekler niteliktedir. Bu bağlamda Güzel Sanatlar Eğitimi Bölümü öğrencilerinin düşünme stillerinde sınıflarının etkisi olduğu söylenebilir.

Beşinci alt amaca yönelik olarak, Güzel Sanatlar Eğitimi Bölümü öğrencilerinin düşünme stilleri ile cinsiyetleri arasında anlamlı bir ilişki olmadığı tespit edilmiştir. Bu bulguya bakılarak Güzel Sanatlar Eğitimi Bölümlerinde öğrenim gören kadın ve erkek öğrencilerin tercih ettiği düşünme stilleri arasında anlamlı fark olmadığı söylenebilir. Bu araştırma, Çubukçu (2004), Saracaloğlu, Yenice ve Karasakaloğlu (2008), Kaya (2009), Tortop, Çalışkan ve Dinçer (2012), Durdukoca (2011) ve Tüzer (2016) tarafından hazırlanan çalışmaların sonuçları ile paralellik göstermektedir. Ancak Buluş (2005), Artut ve Bal (2008), Dinçer (2009), Fer (2005), Merdin (2010), Oflar (2010), Balgalmış ve Baloğlu (2010), Emir (2011), Esmer (2013), Kavgaoğlu ve Altun (2016), Uyanık (2017), Akçay (2018a), Akçay (2018b), Akçay (2019), Değirmenci, Kurt, Akıncı ve Orhon (2017) ve yine Akınc1, Kurt, Değirmenci ve Orhon (2017) tarafından hazırlanan çalışmalarda cinsiyetlere göre düşünme stillerinde anlamlı farklılık görülmektedir.

Araştırmanın altıncı alt amacı doğrultusunda, Güzel Sanatlar Eğitimi Bölümü öğrencilerinin düşünme stilleri ile yaşları arasındaki ilişki incelendiğinde anlamlı bir ilişki olmadığı belirlenmiştir. Bu araştırmanın sonuçları, Oflar (2010), Tüzer (2016), Tortop, Çalışkan ve Dinçer (2012) ve Saracaloğlu, Yenice ve Karasakaloğlu (2008) tarafından hazırlanan çalışmaların sonuçlarını destekler niteliktedir. Fakat Buluş (2005), Dinçer (2009), Merdin (2010), Balgalmış ve Baloğlu (2010) ve Emir (2011)'in çalışmalarına bakıldığında yaş değişkeni ile düşünme stilleri arasında anlamlı farklılık göstermesi sebebiyle karşıtlık göstermektedir. Araştırmanın bu sonucuna göre Güzel Sanatlar Eğitimi Bölümü öğrencilerinin, yaşlarının düşünme stillerine etkisi olmadığı söylenebilir. Fakat Güzel Sanatlar Eğitimi Bölümlerinde yapılacak araştırma sonuçlarının, durumun açıklığa kavuşturulmasında daha etkili olacaktır.

Araştırmanın yedinci alt amacı kapsamında, Güzel Sanatlar Eğitimi Bölümü öğrencilerinin düşünme stilleri ile sanatsal, kültürel ve sportif etkinlikleri uygulama durumları arasındaki ilişkinin incelenmesi ile ilgili bulgulara bakıldığında en az bir kez tiyatroya gitmiş öğrencilerin yargı ve hiyerarşik düşünme stili puanları, en az bir kez sergiye gitmiş öğrencilerin yargı hiyerarşik, anarşik, içsel ve liberal düşünme stili puanlarının, en az bir kez spor yapmış öğrencilerin hiyerarşik, lokal ve dışsal düşünme stili puanlarının, hiç yapmamışlara göre anlamlı düzeyde daha fazla olduğu görülmektedir. Çubukçu (2004)'nun araştırmasında öğrencilerin uyguladığı kitap okuma, gazete okuma, spor yapma, sinemaya gitme ve tiyatroya gitme aktivitelerin yasama, yürütme ve dişsal düşünme stillerinde etkili olduğu sonucuna ulaşılması sebebiyle bu araştırmanın sonucu ile benzer niteliktedir. Öğrencilerin düşünme stilleri ile yapmış oldukları sanatsal, kültürel ve sportif aktiviteler ile arasındaki ilişkiye yönelik bulguların sonuçlarına göre Güzel Sanatlar Eğitimi Bölümü öğrencilerinin tiyatroya gitme, sergiye gitme ve spor yapma etkinliklerinin düşünme stillerinde etkili olduğu; konsere gitme, sinemaya gitme, gazete okuma ve kültürel dergi okuma durumlarının etkili olmadığı söylenebilir. Ancak literatür taramasında, araştırmanın bu sorusuna yönelik bulgu ile ilgili benzer bir araştırmaya rastlanmadığı için Güzel Sanatlar Eğitimi Bölümlerinde yapılacak araştırma sonuçlarının, durumun açıklığa kavuşturulmasında daha etkili olacağı düşünülmektedir.

Sekizinci alt amaca yönelik olarak, Güzel Sanatlar Eğitimi Bölümü öğrencilerinin düşünme stilleri ile akademik not ortalamaları arasında anlamlı ilişki olmadığı görülmüştür. Literatürde elde edilen çalışmalardan, mesleki müzik eğitimi alan öğrencilerin çalışma grubu olduğu Akçay (2019)'ın araştırması, akademik başarı değişkeni ile düşünme stillerinin anlamlı fark göstermemesi sebebiyle bu araştırmayı destekler niteliktedir. Ancak bu araştırma, müzik öğretmenliği bölümü öğrencilerinin çalışma grubu olduğu yine Akçay (2018a)'ın hazırladığı çalışmanın, öğrencilerin düşünme stillerinin akademik not ortalamasına göre değişkenlik gösterdiği için bu araştrımayı destekler nitelikte değildir. Bu sonuçların yanı sıra Güzel Sanatlar Eğitimi Bölümleri dışında gerçekleştirilen çalışmalardan Buluş (2005)'un, Çatalbaş (2006)'ın, Dinçer (2009)'in, Merdin (2010)'in, Emir (2011)'in ve Saracaloğlu, Yenice ve Karasakaloğlu (2008)'nun çalışmalarında anlamlı düzeyde farklılık görüldüğü için bu araştırmanın sonuçları ile uyum göstermemektedir. 
Araştırmada elde edilen sonuçlar doğrultusunda konuyla ilgili olarak aşağıda sıralanan önerilen getirilebilir;

- Bu araştırma 2018-2019 eğitim öğretim yılında Çanakkale Onsekiz Mart Üniversitesi Eğitim Fakültesi Güzel Sanat Eğitimi Bölümü Resim-İş Öğretmenliği ve Müzik Öğretmenliği programlarında öğrenim gören öğrencileri kapsamaktadır. Güzel Sanatlar Eğitimi Bölümü öğrencilerinin düşünme stillerine yönelik yapılacak daha kapsamlı çalışmalar, daha açıklayıcı bilgilere ulaşılmasını sağlayabilir.

- Araştırmada Güzel Sanatlar Eğitimi Bölümü öğrencileri tarafından, en çok yasama, liberal ve yargısal düşünme stilinin en az ise muhafazakâr stilin kullanılması sebebiyle öğrencilere uygulanacak eğitimin mümkün olduğunca geleneksellikten uzak, işlevsel olarak yenilikçi ve yaratıcı temelli olabilir. Aynı zamanda düşünme stilleri dikkate alınarak, verilen proje ve çalışmaların stillerine uygun olmasına özen gösterilebilir.

- Öğretmen adayı olan öğrenciler, ileride onlar tarafindan verilecek eğitimin daha etkili olması için kendi düşünme stillerinin farkında olarak, farklı durumlara göre düşünme stillerini kullanma becerilerini geliştirebilir.

- Öğrencilere uygulanan öğretimde düşünme eğitimine yer verilerek ya da düşünme stillerini temel alan kurs, seminer ya da konferanslar düzenlenerek, öğrencilerin düşünme stilleri ile ilgili bilinçlendirilip kendi düşünme stillerini nasıl ve ne derece kullandıklarına yönelik öz farkındalıklarının arttırılması sağlanmalıdır.

- Her öğrencinin bireysel olarak farklı düşünme stillerine sahip olması sebebiyle, farklı stillere sahip öğrencilerin birbiriyle daha uyumlu çalışabilmesine yönelik geliştirilecek yöntemlerin uygulanması ile öğrenme ve çalışma verimliliklerinin artacağı düşünülmektedir. Örneğin global düşünme stilini kullanan bir öğrenci ile lokal düşünme stilini kullanan başka bir öğrencinin birlikte uyumlu bir şekilde çalışması yalnız çalışmalarına oranla daha etkili olabilir.

- Birbirinden farklı bölümlerde öğrenim gören öğrenciler ve farklı branşlardaki öğretmenler ile uygulanan çalışmalarda, düşünme stilleri ile yaş, cinsiyet sınıf, bölüm, aile eğitim düzeyi, aile gelir düzeyi ve çeşitli etkinlikleri uygulama durumlarının birbirine etkisi incelendiğinde farklı sonuçlara ulaşılmıştır. Bu sebeple, özellikle Güzel Sanatlar Eğitimi Bölümlerinde öğrenim gören öğrencilerin düşünme stilleri ile farklı değişkenler arasındaki ilişkinin incelenmesi, Resim-İş Öğretmenliği ve Müzik Öğretmenliği Anabilim Dallarına faydalı olacağı düşünülmektedir.

$\mathrm{Bu}$ araştırmada Güzel Sanatlar Eğitimi Bölümü öğrencilerinin düşünme stilleri, Zihinsel-Benlik Yönetimi Kuramına göre incelenmiştir. Bu bölümde öğrenim gören öğrencilerin farklı kuramlara göre düşünme becerileri incelenerek yeni araştırmalar yapılabilir.

\section{Kaynakça}

Akçay, Ş. Ö. (2018a). Müzik öğretmeni adaylarının düşünme stilleri üzerine inceleme. 27. Uluslararası Eğitim Bilimleri Kongresi. 27, 37-51. Erişim adresi: https://www.researchgate.net

Akçay, Ş. Ö. (2018b). Müzik öğretmenlerinin düşünme stillerinin çeşitli değişkenlere göre incelenmesi. Sosyal Bilimler Dergisi / The Journal of Social Science, 5(28), 184-199. doi: http://dx.doi.org/10.16990/SOBIDER. 4459

Akçay, Ş. Ö. (2019). Mesleki müzik eğitimi alan öğrencilerin düşünme stilleri ile çeşitli değişkenler arasındaki ilişkinin incelenmesi. Kastamonu Eğitim Dergisi, 27(2), 683-700. doi: 10.24106/kefdergi.2687

Akıncı, M., Kurt, A., Değirmenci, A., \& Orhon, G. (2017). Türkçe ve İngilizce öğretmeni adaylarının düşünme stillerinin zihinsel öz-yönetim kuramına göre incelenmesi. Anadolu Üniversitesi Ĕ̆itim Fakültesi Dergisi, 1(1), 1-16. Erişim adresi: https://dergipark.org.tr/tr/download/article-file/408641

Arkonaç, S. (1993). Psikoloji: Zihin süreçleri Bilimi. İstanbul: Alfa Yayınları.

Artut, P., \& Bal, P. (2008). Lise öğrencilerinin geometri başarısı ve düşünme stillerinin karşılaştırılması. Ç. $\ddot{U}$. Sosyal Bilimler Enstitüsü Dergisi, 17(1), 1-10. Erişim adresi: https://dergipark.org.tr/tr/download/articlefile/50408

Balgalmış, E., \& Baloğlu, M. (2010). Eğitim yöneticilerinin düşünme stilleri açısından çeşitli değişkenlere göre incelenmesi. Hacettepe Üniversitesi Eğitim Fakültesi Dergisi, 38, 1-10. Erişim adresi: http://www.efdergi.hacettepe.edu.tr/cilt-sayi-38-yil-2010.html

Buluş, M. (2005). İlköğretim bölümü öğrencilerinin düşünme stilleri profili açısından incelenmesi. Ege Eğitim Dergisi, 6(1), 1-24. Erişim adresi: https://dergipark.org.tr/tr/download/article-file/57089

Buluş, M. (2006). Düşünme stilleri ölçeğinin güvenirliği ve geçerliği, akademik başarı ve öğretmen adayları özellikleri. Eğitim ve Bilim, 31(139), 35-48. Erişim adresi: http://egitimvebilim.ted.org.tr/index.php/EB/ article/view/4983/1087 
Çatalbaş, E. (2006). Lise ögrrencilerinin düşünme stillerinin akademik başarı ve tutumlarl arasındaki ilişki (Yüksek Lisans Tezi). YÖK tez veri tabanından erişildi (Tez No. 189369).

Çubukçu, Z. (2004). Öğretmen adaylarının düşünme stillerinin belirlenmesi. Trakya Üniversitesi Sosyal Bilimler Dergisi, 6(2), 87-106. Erişim adresi: https://dergipark.org.tr/tr/download/article-file/321848

Değirmenci, A., Kurt, A., Akınc1, M., \& Orhon, G. (2017). Eğitim fakültesi temel ĕ̌itim bölümü öğretmen adaylarının düşünme stillerinin çeşitli değişkenler açısından incelenmesi. Ö. Demirel ve S. Dinçer (Ed.), Küreselleşen Dünyada eğitim (s. 199-208) içinde. Erişim adresi: https://www.researchgate.net/publication/ 320981501_Egitim_fakultesi_temel_egitim_bolumu_ogretmen_adaylarinin_dusunme_stillerinin_cesitli_degi skenler_acisindan_incelenmesi

Dinçer, B. (2009). Öğretmen adaylarının düşünme stilleri profillerinin çeşitli değişkenler açısından değerlendirilmesi (Yüksek Lisans Tezi). YÖK tez veri tabanından erişildi (Tez No. 240078).

Durdukoca, Ş. (2011, 27-29 Nisan). Öğretmen adaylarının düşünme stillerinin çeşitli değişkenlere göre incelenmesi. 2nd International Conference on New Trends in Education and Their Implications içinde sunulan bildiri, Porto Bello Hotel Resort \& SPA, Antalya.

Emir, S. (2011). Düşünme stillerinin farklı değişkenler açısından incelenmesi. İstanbul Üniversitesi Hasan Ali Yücel Ë̆itim Fakültesi Dergisi, 8(1), 77-93. Erişim adresi: https://hayefjournal.org/en/dusunme-stillerininfarkli-degiskenler-acisindan-incelenmesi-16690

Erden, M., \& Akman, Y. (2014). Eğitim psikolojisi (21. Basım). Ankara: Arkadaş Yayınevi.

Esmer, E. (2013). Öğretmen adaylarının zihinsel stil tercihlerinin (düşünme stillerinin) incelenmesi (Yüksek Lisans Tezi). YÖK tez veri tabanından erişildi (Tez No. 339349).

Fer, S. (2005, 28-30 Eylül). Aday öğretmenlerin düşünme stilleri nedir? XIV. Ulusal Eğitim Bilimleri Kongresinde sunulan bildiri, Pamukkale Üniversitesi Eğitim Fakültesi, Denizli.

Karasar, N. (1995) Araştırmalarda rapor hazırlama (8. Basım). Ankara: 3A Araştırma Eğitim Danışmanlık.

Karasar, N. (2012). Bilimsel araştırma yöntemi. Ankara: Nobel Yayınları.

Kavgaoğlu, D., \& Altun, S. (2016). Öğretmenlerin düşünme stillerinin branşa ve cinsiyete göre incelenmesi. The Journal of International Education Sciences 3(6), 36-149. doi: http://dx.doi.org/10.16991/INESJOURNAL. 224

Kaya, B. (2009). İlköğretim 6-7-8. sınıf ögrencilerinin düşünme stilleri ile matematik akademik başarılarının okul türüne, cinsiyete ve sinıf düzeyine göre incelenmesi (Yüksek Lisans Tezi). YÖK tez veri tabanından erişildi (Tez No. 240189).

Merdin, S. (2010). Lise ögrencilerinin düşünme stilleri (Yüksek Lisans Tezi). YÖK tez veri tabanından erişildi (Tez No. 249644).

Oflar, Y. (2010). Illköğretim okulu öğretmenlerinin düşünme stilleri (Yüksek Lisans Tezi). YÖK tez veri tabanından erişildi (Tez No. 263476).

Özer, S. (2016). Düşünme stillerine göre farklılaştırılmış öğretim etkinliklerinin öğrencilerin erişlerine, mesleki yabancı dil dersine yönelik tutumlarına ve ögrenilenlerin kalıcılı̆̆ına etkisi (Doktora Tezi). YÖK tez veri tabanından erişildi (Tez No. 430674).

Saracaloğlu, A., Yenice, N., \& Karasakaloğlu, N. (2008). Eğitim fakültesi öğrencilerinin düşünme stillerinin çeşitli değişkenler açısından incelenmesi. Uluslararası Sosyal Araştırmalar Dergisi, 1(5), 732-751. Erişim adresi: http://www.sosyalarastirmalar.com/cilt1/sayi5/sayi5pdf/saracaloglu_yenice_karasakaloglu.pdf

Sternberg, R. J. (1999). Thinking styles. UK: Cambridge University Press.

Sternberg, R. J., \& Lubart, T. I. (1991). An investment theory of creativity and its development. Human Development, 34(1), 1-31. doi: https://doi.org/10.1159/000277029

Sternberg, R. J., \& Wagner, R. K. (1992). Thinking styles inventory, unpublished test. Yale: Yale University.

Şahin, D., \& Yağçı, M. M. (2012). Bireyin toplumsallaşma sürecinde sanat eğitiminin önemi. Batman Üniversitesi Yaşam Bilimleri Dergisi, 1(1), 273-277. Erişim adresi: https://dergipark.org.tr/tr/download/article-file/313554

Tortop H. S., Çalışkan G., \& Dinçer M. (2012). Öğretmen adaylarının kişilikleri ile düşünme stilleri arasındaki ilişskinin incelenmesi. Mustafa Kemal Üniversitesi Sosyal Bilimler Enstitüsü Dergisi, 9(19), 307-319. Erişim adresi: https://dergipark.org.tr/tr/download/article-file/183063 
Tufan, S., \& Coşkun, G. (2009, 23-25 Eylül). Müzik eğitimi anabilim dalı öğrencilerinin düşünme stilleri. 8. Ulusal Müzik Eğitimi Sempozyumunda sunulan bildiri, Samsun. Erişim adresi: http://www.muzikegitimcileri. net

Tüzer, L. (2016). Sınıf öğretmenlerinin düşünme stillerinin çeşitli değişkenlere göre incelenmesi (Yüksek Lisans Tezi). YÖK tez veri tabanından erişildi (Tez No. 422550).

Uyanık, N. (2017). Eğitim fakültesi ögrencilerinin düşünme stileri ile düşünme ihtiyaçları arasındaki ilişkinin incelenmesi (Yüksek Lisans Tezi). YÖK tez veri tabanından erişildi (Tez No. 470234). 